\title{
Studi Terhadap Program Housing Bagi Kawasan Terdampak Perusahaan Tambang
}

\author{
Zainal Fadri \\ Fakultas Ushuluddin Adab dan Dakwah IAIN Batusangkar \\ zainalfadri@iainbatusangkar.ac.id
}

\begin{abstract}
Housing and its policy become an interesting issue for the study of social development programs. The CSR program in the housing sector is a form of company involvement in fulfilling access to housing needs as a social responsibility for the impact of company activities on the surrounding community. The method used in this paper is the method of literature or library research, namely by collecting reading material from books, as well as research journals on CSR programs in the housing sector, then analyzing with a qualitative approach so as to produce conclusions as a closing paper. The conclusions in this paper describe the CSR program in the housing sector of PT. Aneka Tambang was carried out in the Nanggung, sub-district of Bogor district. CSR activities are carried out through the home improvement competition program and the implementation of a bealthy bome improvement. CSR program in the housing sector by PT. Aneka Tambang is a form of company involvement in improving people's welfare as a joint commitment between the government, the private sector and the community.
\end{abstract}

Keywords: CSR; Housing Program; PT. Antam

\begin{abstract}
Abstrak
Perumahan (housing) dan kebijakan perumahan (housing policy) menjadi isu yang menarik untuk kajian program-program pembangunan sosial. Program CSR bidang perumahan merupakan bentuk keterlibatan perusahaan dalam pemenuban akses kebutuban perumahan sebagai tanggungjawab sosial atas dampak aktivitas perusabaan terhadap masyarakat sekitar. Metode yang digunakan dalam paper ini adalah metode kepustakaan atau library research, yaitu dengan mengumpulkan bahan bacaan dari buku, maupun jurnal penelitian mengenai program CSR bidang perumahan, kemudian dilakukan analisis dengan pendekatan kualitatif sehingga menghasilkan kesimpulan sebagai closing paper. Kesimpulan dalam paper ini menggambarkan program CSR bidang perumahan PT. Aneka Tambang yang dilaksanakan di kecamatan Nanggung kabupaten Bogor. Kegiatan CSR dilaksanakan melalui program lomba perbaikan rumah dan pelaksanaan perbaikan rumah sehat. Prgram CSR bidang perumahan oleh PT. Aneka Tambang merupakan bentuk keterlibatan perusahaan atas peningkatan kesejabteraan bidup masyarakat sebagai komitmen bersama antara pemerintah, swasta dan komunitas masyarakat.
\end{abstract}

Kata Kunci: CSR; Program Housing; PT. Antam 


\section{A. Pendahuluan}

Kemiskinan dapat dikatakan sebagai awal munculnya persoalan perumahan tidak layak huni. Keluarga dalam pengertian ini adalah masyarakat yang memiliki tempat tinggal tidal layak huni terkesan memiliki keterbatasan ekonomi sehingga alasan yang sering dikeluarkan kepada publik adalah ketidakmampuan untuk memenuhi kebutuhan hidup akan perumahan. Masyarakat yang berkekurangan, hidup dengan keadaan seadanya dan tempat tinggal yang jauh dikatakan sebagai tempat tinggal dengan layak kesehatan maupun yang telah memenuhi standar keamanan.

Kemiskinan yang melanda sebagian besar masyarakat tidak lepas dari peranan krisis yang terjadi di dalam suatu negara. Krisis menyebabkan suatu kemiskinan berlanjut bahkan terdapat indikasi ketidakpercayaan masyarakat terhadap negara ${ }^{1}$ sehingga masyarakat miskin lebih memilih untuk menjalani hidup dengan cara mereka sendiri. Banyak masyarakat yang memenuhi kebutuhan perumahan hanya dengan menggunakan bahan-bahan bekas dan sangat tidak layak dikatakan sebagai terpenuhinya kebutuhan papan untuk kelangsungan kehidupan.

Pemenuhan kebutuhan perumahan pada masyarakat sangat dipengaruhi oleh pertumbuhan penduduk dengan laju angka yang tinggi sehingga kebutuhan akan papan merupakan kebutuhan mendesak untuk dipenuhi. Permasalahan yang sering ditemui adalah ketidakseimbangan laju penduduk dengan ketersediaan bahan maupun modal untuk membangun perumahan, sehingga banyak masyarakat yang hidup dengan kondisi rumah tidak layak. United Nation Statistical Office pernah melakukan tinjauan laju penduduk di beberapa kawasan dalam rentang waktu 20 tahun (tahun 1990-2010), di dalam data tersebut memperlihatkan perkembangan penduduk yang sangat signifikan ${ }^{2}$ yaitu:

\footnotetext{
${ }^{1}$ Nanik Sudarwati, Kebijakan Pengentasan Kemiskinan, (Malang: Intimedia, 2009), Hal. 87

${ }^{2}$ Orville F. Grimes, Housing for Low-Income Urban Families, (New York: The World Bank, 2001),
} Hal. 5 
Tabel.1 Perkembangan Urban Population 20 Tahun

\begin{tabular}{|l|c|c|c|}
\hline \multirow{2}{*}{ Developing Region } & \multicolumn{2}{|c|}{ Urban population (millions of persons) } & $\begin{array}{c}\text { Average } \\
\text { Annual } \\
\text { Growth }\end{array}$ \\
\hline Africa & $\mathbf{1 9 9 0}$ & $\mathbf{2 0 1 0}$ & 4.8 \\
\hline Asia & 112 & 289 & 3.8 \\
\hline Latin America & 646 & 1.365 & 3.4 \\
\hline Total & 237 & 464 & $\mathbf{3 . 8}$ \\
\hline
\end{tabular}

Sumber: U.N. Statistical Office, 2019

Data di atas menunjukan laju penduduk dalam rentan 20 tahun rata-rata memiliki peningkatan hingga dua kali lipat. Termasuk di Indonesia sebagai bagian kawasan Asia dan memiliki jumlah penduduk yang besar. Jumlah penduduk yang banyak menjadikan persoalan perumahan (housing) menjadi pemasalahan dasar yang harus diselesaikan.

Tabel.2 Perkembangan Populasi di Indonesia

\begin{tabular}{|l|c|c|c|}
\hline Provinsi dengan & Jumlah Populasi (juta orang) & Rata-rata \\
\cline { 2 - 3 } Populasi Tertinggi & $\mathbf{1 9 9 0}$ & $\mathbf{2 0 1 0}$ & Perkembangan \\
\hline Jawa Barat & 38.5 & 43.1 & 1.9 \\
\hline Jawa Timur & 34.8 & 37.5 & 1.5 \\
\hline Jawa Tengah & 31.2 & 32.4 & 1.1 \\
\hline Sumatera Utara & 11.8 & 13.0 & 1.4 \\
\hline Banten & 8.1 & 10.6 & 1.2 \\
\hline \multicolumn{3}{|c|}{ Sumber: Indonesia Investment, 2019 } \\
\hline
\end{tabular}

Perkembangan populasi Indonesia yang begitu pesat menjadi patokan dalam menyelesaikan persoalan dalam meningkatkan problem solving terutama di bidang perumahan atau housing. Dari data di atas terlihat bahwa perkembangan populasi masyarakat di Indonesia tertinggi terdapat pada Jawa Barat, sehingga program yang akan dilaksanakan oleh PT. Antam merupakan sebuah jawaban atas persoalan yang dimiliki provinsi.

Permasalahan yang selalu timbul adalah perumahan yang tidak memiliki standar sesuai dengan aturan maupun regulasi yang diturunkan sebagai batasan dan aturan minimal terhadap perumahan yang dapat dianggap layak. Perumahan yang dapat dianggap layak dengan menyesuaikan kebutuhan yang harus dipenuhi oleh suatu keluarga atau suatu masyarakat tertentu akan menjadikan suasana tentram dan damai pada suatu lingkungan yang disebut rumah. Persoalan di Indonesia 
masih banyak rumah atau perumahan yang belum dapat dikatakan layak sebagai standar minimum rumah untuk dikatakan sebagai rumah sehat dan nyaman.

Kekurangan sanitasi layak dan air layak minum memperlihatkan perumahan belum menjadi tempat tinggal yang aman dan nyaman untuk masyarakat dalam beraktivitas $^{3}$. Aktivitas masyarakat menjadi terganggu karena tempat tinggal yang dimiliki tidak memiliki standar kesehatan. Banyak ancaman dan tantangan untuk kesehatan maupun kelangsungan hidup suatu rumah tangga untuk menjalani kehidupan dan aktivitas. Namun jauh dari pada itu sudah banyak terdapat komitmen-komitmen baik secara global maupun nasional yang memperjuangkan mengenai perumahan layak, termasuk kelayakan dalam pemenuhan kepemilikan atas rumah.

Secara global hak untuk mendapatkan rumah dan perumahan yang layak disampaikan dalam deklarasi HAM ke-25 (Declaration of Human Rights-25) yang menyebutkan:

"Everyone has the right to a standard of living adequate for the health and well-being of bimself and of his family, including food, clothing, housing, and medical care and necessary social services, and the right to security in the event of unemployment, sickness, disability, widowhood, old age, or other lack of livelihood in circumstances beyond his control'.

Deklarasi ini berbicara mengenai hak seseorang atau suatu keluarga dalam memiliki tempat tinggal sesuai standar yang dapat menunjang kegiatan untuk penghidupan yang lebih baik.

Komitmen untuk perumahan juga telah dikeluarkan oleh pemerintah Indonesia yang tertuang dalam Undang-Undang Nomor 4 tahun 1992 yang berbunyi "Rumah merupakan bangunan yang berfungsi sebagai tempat tinggal atau hunian dan sarana pembinaan keluarga, sedangkan perumahan adalah kelompok rumah yang berfungsi sebagai lingkungan tempat tinggal atau lingkungan hunian yang dilengkapi dengan prasarana dan sarana lingkungan”, serta ditegaskan dan didukung oleh Undang-Undang Nomor 39 tahun 1999 Pasal 40 yang menyatakan "Setiap orang berhak untuk bertempat tinggal serta berkehidupan yang layak."

3 A. Zaenurrossyid \& Ahmad Nuruddin, "Modal Sosial Pesantren Jawa Pesisiran Utara dalam Pemberdayaan Masyarakat", Islamic Review: Jurnal Riset dan Kajian Keislaman, 8(1), 2019 
Komitmen yang dideklarasikan dalam bentuk Undang-Undang ataupun dalam bentuk Community Declaration merupakan bentuk nyata dalam mengupayakan dalam pemenuhan kebutuhan yang menjadi landasan kebijakan diturunkannya persebaran perumahan yang layak bagi seluruh masyarakat. Bentuk komitmen secara umum yang dideklarasikan adalah regulasi tahap awal dalam proses pemilikan dan penggunaan perumahan sehingga dapat menunjang kehidupan yang lebih baik, meskipun keadaan di lapangan belum mencapai seluruh tujuan tersebut. Banyak peraturan maupun perundang-undangan yang mengatur dan mengarahkan pada hak dan kepemilikan rumah dengan segala standar seringkali hanya merupakan bentuk formal yang tidak terlihat pelaksanaannya.

Peran negara sangat diperlukan dalam urusan kedaulatan ${ }^{4}$ perumahan yang akan menjadikan masyarakat memiliki tempat tinggal yang layak dan memiliki standar sesuai dengan kesehatan yang akan menunjang aktivitas dan kehidupan sehari-hari. Peran negara terhadap jaminan masyarakat atas hak dalam memiliki perumahan dapat diwujudkan dengan menggali persoalan yang terdapat pada persoalan perumahan ditambah dengan menjamin ketersediaan serta kebijakan yang pro terhadap masyarakat, ${ }^{5}$ sehingga menciptakan keamanan dan kesehatan sebagai bentuk jaminan atas masyarakat dari suatu negara. Jaminan keamanan dan ketersediaan rumah menjadi bentuk pemeliharaan masyarakat sebagai warga negara terhadap kemungkinan bentuk eksistensi pemerintah suatu negara dalam berhubungan dengan warga negara. ${ }^{6}$

Perumahan menjadi persoalan yang menarik untuk dibahas dalam permasalahan kedaulatan warga masyarakat sebagai model jaminan dari negara. Jaminan yang diberikan negara belum mencapai tingkat kepuasan dalam pengelolaan maupun dalam menjalankan program sesuai dengan komitmen yang

\footnotetext{
${ }^{4}$ Zainal Fadri, "Tabuik: Local Wisdom as an Alternative for Suppressing the Impact of Structural Change in Pariaman", Alfuad: Jurnal Sosial Keagamaan, 3(1), 2019, Hal. 98

5 Aprodicio A. Laquian, Basic Housing: Policies for Urban Sites, Services, and Shelter in Developing Countries, (Ottawa: International Development Research Center, 1983), Hal. 147

${ }^{6}$ Peter Malpass, "Housing Policy and the Housing System", dalam Implementing Housing Policy, (Buckingham: Open University Press, 1993), Hal. 24
} 
diberikan. Komitmen-komitmen negara yang belum mencapai tahap maksimal ${ }^{7}$ meninggalkan model perumahan yang tidak layak baik dari kesehatan maupun keamanan, menjadi suatu persoalan yang harus diselesaikan dengan segera. Permasalahan muncul ketika negara tidak mampu menjangkau pesoalan perumahan maka pihak swasta atau private sector menjadi suatu instansi mengambil langkah untuk menyelesaikan persoalan tersebut. Pihak swasta dalam persoalan ini adalah perusahaan yang memiliki aktivitas di sekitar kehidupan warga masyarakat memiliki kewajiban untuk menunjang kehidupan warga sebagai bentuk tanggungjawab sosial atas kegiatan yang dilakukan.

Salah satu kegiatan tanggungjawab sosial (CSR) dapat dilakukan dengan program perumahan atau sering juga disebut dengan istilah bedah rumah. Program bedah rumah dengan motode-metode khusus sesuai dengan visi misi perusahaan menjadi bentuk suatu komitmen bersama yang dijalankan dalam menciptakan suatu keadaan kehidupan masyarakat menjadi aman dan damai terutama di bidang perumahan dan lingkungan tempat tinggal. Rumah yang memiliki standar kesehatan dan keamanan menjadi tujuan utama dari program CSR bidang perumahan. Program CSR yang diambil pada tulisan ini adalah program yang dilakukan PT. Aneka Tambang Tbk. yang telah menjalankan program bedah rumah disekitar aktivitas perusahaan dengan berbagai metode, sehingga diharapkan masyarakat dapat menikmati kehidupan dan tempat tinggal yang layak sebagai tempat beraktivitas dalam kehidupan sehari-hari.

\section{B. Hasil dan Pembahasan}

\section{Program Housing PT. Aneka Tambang Tbk.}

PT. Aneka Tambang Tbk. merupakan Badan Usaha Milik Negara (BUMN) yang memiliki fokus pada aktivitas pertambangan yang pada awalnya merupakan gabungan dari PT. Nikel Indonesia, PT. Tambang Bauksit Indonesia, PN Logam Mulia, BPU Perusahaan Tambang Umum Negara, Proyek Pertambangan Intan Martapura Kalimantan Selatan, PN Tambang

7 Zainal Fadri, "Upaya Penanggulangan Gelandangan Dan Pengemis (Gepeng) Sebagai Penyandang Masalah Kesejahteraan Sosial (PMKS) Di Yogyakarta", Komunitas, 10(1), 2019, Hal. 5 
Emas Cikotok, dan Proyek Emas Logas. PT. Aneka Tambang didirikan pada tanggal 5 Juli 1968. PT. Aneka Tambang memiliki lokasi perindustrian dan aktivitas pertambangan tersebar di seluruh wilayah Indonesia, namun pada persoalan ini, PT. Aneka Tambang dilihat dari program CSR melalui kegiatan bedah rumah yang dilaksanakan di daerah Jawa Barat, lebih tepatnya di kecamatan Nanggung kabupaten Bogor.

Pelaksanaan CSR oleh perusahaan merupakan suatu langkah ideal yang dilakukan oleh perusahaan dalam melakukan tanggungjawab etis, ekonomi dan society untuk kehidupan serta hubungan yang lebih baik antara perusahaan dan masyarakat. Standar yang dikeluarkan sebagai landasan CSR dengan pengelolaan bisnis untuk profit tanpa mengesampingkan persoalan masyarakat serta menjunjung tinggi persoalan lingkungan hidup ${ }^{8}$ yang sering dikenal dengan istilah profit, planet dan peoples. PT. Aneka Tambang melaksanakan program CSR melalui kegiatan bedah rumah yang dilaksanakan di kecamatan Nanggung, kabupaten Bogor sebagaimana daerah tersebut merupakan daerah tempat beroperasinya aktivitas pertambangan PT. Aneka Tambang.

Secara umum pelaksanaan program CSR PT. Aneka Tambang di bidang perumahan berawal dari keresahan yang dirasakan pihak pengelola yang didorong oleh pemerintahan setempat. Kecamatan Nanggung kabupaten Bogor merupakan daerah yang langsung berhubungan dengan aktivitas pertambangan sehingga kemungkinan dampak yang diberikan oleh PT. Aneka Tambang akan dirasakan langsung oleh sebagian besar masyarakat. Pelaksanaan program CSR dilakukan untuk meminamalisir kemungkinan ternjadinya konflik antara masyarakat sekitar dengan perusahaan akibat pertambangan. ${ }^{9}$ Konflik yang terjadi diyakini dapat menimbulkan suatu reaksi dari masyarakat sehingga dapat menjalar pada kelompok yang lebih besar dalam aksi yang kemudian akan

${ }^{8}$ Amartya Sen, "Economics, Business Princples, and Moral Sentiments", dalam Business Ethics: Vol I, Ethical Theory, Distibutive Justice, and Social Responsibility, (London: SAGE Publication Inc. 2006), Hal. 266

${ }^{9}$ Tom L. Beauchamp, Cause Studies in Business, Society, and Ethics, (New Jersey: Englewood Cliffs. 1989) Hal. 190 
menciptakkan suatu hubungan yang tidak nyaman antara perusahaan dan masyarakat.

Program CSR bidang perumahan PT. Aneka Tambang dilaksanakan dengan berbagai model kegiatan. Kegiatan yang paling terlihat hasilnya adalah melalui program bedah rumah dengan model lomba perbaikan rumah dan program perbaikan rumah sehat. Kegiatan lomba perbaikan rumah merupakan konsep bedah rumah yang diselenggarakan oleh PT. Aneka Tambang degan metode perbaikan rumah yang dilakukan oleh masyarakat serta pemilik rumah dengan harapan tercipta kerjasama dan gotong-royong antar warga masyarakat dalam melakukan bedah rumah. Sementara perbaikan rumah sehat merupakan program PT. Aneka Tambang dalam memperbaiki rumah yang menempati posisi urgent untuk dilakukan bedah rumah, terutama untuk persoalan sanitasi dan kesehatan.

\section{a. Lomba Perbaikan Rumah}

Lomba perbaikan rumah antar desa yang dilaksanakan oleh PT. Aneka Tambang merupakan salah satu program dari Bina Lingkungan (BL) yang disusun oleh Satuan Kerja Pengembangan Masyarakat yang terdapat dalam program CSR PT. Aneka Tambang cabang pertambangan Pongkor. Program lomba perbaikan rumah dilaksanakan untuk peningkatan mutu kesehatan serta kepedulian terhadap rumah layak ${ }^{10}$ yang akan menjadi suatu model tempat tinggal dan tempat dalam menjalankan aktivitas sehari-hari.

Lomba perbaikan rumah sebagai program CSR PT. Aneka Tambang di bidang perumahan memiliki alur layaknya hibah dalam suatu pembangunan perumahan. Masyarakat yang akan memperbaiki rumah sesuai dengan program harus melakukan beberapa hal, ${ }^{11}$ yaitu:

1) Pengajuan proposal terlebih dahulu sebagai bentuk permintaan pengajuan perbaikan rumah.

${ }^{10}$ Musrifah, Penerapan Corporate Social Responsibility (CSR) bidang Perumahan pada Wilayah Binaan PT. Aneka Tambang Tbk. di Kecamatan Nanggung Kabupaten Bogor, (Semarang: Universitas Diponegoro, 2010), Hal. 66

${ }^{11}$ Musrifah, Penerapan Corporate... hal. 66 
2) Proposal yang masuk akan dilaksanakan uji validasi dan survai lokasi. Survai dilakukan dalam rangka melihat lokasi tempat dilaksanakan pembangunan dan perbaikan rumah serta melihat apakah rumah yang akan dilakukan perbaikan telah memenuhi kriteria untuk pelaksanaan lomba perbaikan rumah.

3) Proses validasi juga dilakukan dengan model sosialisasi terhadap program yang dilaksanakan oleh PT. Aneka Tambang mengenai lomba perbaikan rumah. Sosialisasi juga mencakup perihal program CSR serta pengajuan rencana perbaikan rumah, baik dari segi material untuk pembangunan maupun dari tenaga kerja dan desain rumah.

4) Setelah validasi dan sosialisasi, dilaksanakan pencairan dana untuk biaya perbaikan rumah.

5) Pelaksanaan perbaikan rumah serta melakukan monitoring dan penilaian atas kinerja perbaikan rumah. Kinerja perbaikan rumah dinilai dari segi ketepatan waktu, dana, serta keterlibatan masyarakat dalam menjalankan program perbaikan rumah.

6) Pengumuman hasil lomba dan pemberian apresiasi terhadap pemenang lomba perbaikan rumah.

Program CSR bidang perumahan PT. Aneka Tambang melalui lomba perbaikan rumah menjadi salah satu program andalan karena menggabungkan berberapa aspek dalam pelaksanaan suatu program. Lomba perbaikan rumah mengedepankan aspek gotong-royong sebagai bentuk community development dalam suatu pelaksanaan program. Keberhasilan lomba perbaikan rumah akan terlihat pada efektivitas pelaksanaan perbaikan rumah karena modal yang diberikan relatif tidak cukup jika diserahkan dalam bentuk kerja tukang atau kerja proyek. Pengelolaan perbaikan rumah pada lomba perbaikan rumah diserakhan sepenuhnya kepada Kepala Desa yang akan mengatur pelaksanaan dan tata kelola pengerjaan perbaikan rumah. 
Musrifah ${ }^{12}$ menyatakan bahwa pemenang untuk lomba perbaikan rumah mendapatkan penghargaan atau hadiah sesuai dengan juara masingmasing. Pemenang pertama mendapatkan hadiah Rp. 12.500.000, pemenang kedua mendapatkan hadiah Rp. 7.500.000, dan pemenang ketiga mendapatkan hadiah Rp. 5.000.000. Selain hadiah untuk para pemenang, pihak perusahaan juga memberikan sanksi bagi desa yang tidak dapat melaksanakan perbaikan rumah sesuai dengan peraturan yang telah disepakati. Sanksi diberikan dengan mengembalikan biaya perbaikan rumah sebesar Rp. 10.000.000.

\section{b. Perbaikan rumah sehat}

Program pelaksanaan perbaikan rumah sehat dilaksanakan oleh Kepala Desa. Program perbaikan rumah sehat mensyaratkan tiga rumah sebagai satuan minimal untuk dilakukan perbaikan. Penentuan penerima bantuan dilaksanakan oleh Kepala Desa yang diawali dengan musyawarah dengan warga setempat. Perbaikan rumah sehat dilaksanakan sesuai dengan kebutuhan masing-masing desa sehingga menjadikan program atau bentuk bantuan yang diturunkan tidak sama antara desa satu dengan yang lainnya. Musrifah ${ }^{13}$ menyatakan ada beberapa program perbaikan rumah sehat yang dilakukan oleh PT. Aneka Tambang tersebar pada 10 desa.

Perbaikan rumah sehat dilaksanakan sesuai dengan kebutuhan masyarakat yang telah disesuaikan dengan kesepakatan pada musyawarah tingkat desa. Kebutuhan yang telah disepakati menjadi hal yang harus dipenuhi oleh pihak perusahaan dalam menjalankan program perbaikan rumah sehat dengan upaya penyerapan anggaran yang sesuai dengan kebutuhan. Proses pelaksanaan kegiatan perbaikan rumah sehat dipantau langsung oleh pihak perusahaan dengan laporan-laporan kegiatan yang diberikan oleh Kepala Desa selaku pengelola program bantuan perbaikan rumah sehat.

${ }^{12}$ Musrifah, Penerapan Corporate... hal. 67.

${ }^{13}$ Musrifah, Penerapan Corporate... Hal. 49. 
Kriteria penerima bantuan program CSR PT. Aneka Tambang di bidang perumahan ditentukan berdasarkan kondisi sosial yang dialami oleh masyarakat penerima bantuan. Kondisi sosial masyarakat penerima bantuan dilaksanakan dengan pendekatan aspek menurut usia, tingkat pendidikan, jenis pekerjaan, jumlah anggota dan lama tinggal. ${ }^{14}$ Penerima bantuan untuk perbaikan rumah rata-rata masyarakat yang memiliki keterbatasan di bidang ekonomi sehingga memenuhi standar rumah yang sehat merupakan suatu tanggungan berat yang tidak dapat dipenuhi oleh masyarakat. Dari persoalan itulah program CSR PT. Aneka Tambang hadir sebagai bentuk kepedulian terhadap perbaikan rumah guna menunjang kesehatan terutama keluarga masyarakat yang bertempat tinggal di kawasan aktivitas pertambangan.

\section{Pelaksanaan Program Housing di Kabupaten Bogor}

Program CSR di bidang perumahan yang dilaksanakan oleh PT. Aneka Tambang di kecamatan Nanggung kabupaten Bogor merupakan salah satu bentuk tanggungjawab sosial perusahaan terhadap masyarakat yang bertempat tinggal di sekitar aktivitas pertambangan. Sukses atau tidaknya program CSR yang dijalankan terlihat dari keadaan peningkatan kesejahteraan yang dirasakan oleh masyarakat. Masyarakat menjadi rekan bisnis dalam bentuk hubungan sosial yang baik menandakan suatu program CSR perusahaan dapat diakatakan berjalan, dan sebaliknya jika keadaan komunikasi antara masyarakat dan perusahaan buruk dapat dicurigai sebagai bentuk kegagalan program CSR yang akan berdampak lebih besar untuk kegiatan pertambangan yang lebih panjang.

Kelebihan dan kekurangan yang terdapat pada program CSR merupakan bentuk analisis dari program yang dilaksanakan. PT. Aneka Tambang melalui program CSR di bidang perumahan, baik dalam bentuk lomba perbaikan rumah maupun pelaksanaan perbaikan rumah sehat merupakan suatu bentuk kegiatan yang menjadikan PT. Aneka Tambang sebagai lembaga yang paham terhadap persoalan masyarakat di sekitar aktivitas pertambangan terlepas dari penilaian terhadap program-program yang dilaksanakan. Program perumahan dalam

\footnotetext{
${ }^{14}$ Musrifah, Penerapan Corporate... hal. 76.
} 
CSR PT. Aneka Tambang menjadi salah satu contoh konkret tanggungjawab sosial yang dilaksanakan dan dapat digunakan sebagai contoh bagi perusahaan lain, baik dengan aktivitas serupa maupun dengan model lain sesuai dengan visi misi perusahaan yang mengelola.

Di samping keberhasilan program CSR perusahaan PT. Aneka Tambang di bidang perumahan, terdapat beberapa catatan dan pembelajaran yang dapat dianalisis dan dapat dijadikan sebagai bentuk evaluasi sebagai tindak lanjut dari program CSR yang akan dilaksanakan oleh perusahaan lain. Bebrapa hal yang dapat dipetik adalah keterlibatan masyarakat atau community dalam pelaksanaan program, dan implementasi program yang dilakukan untuk kesejahteraan masyarakat. Hal lain yang dapat dikaji dari program CSR PT. Aneka Tambang adalah peran negara dan perusahaan sebagai private sector, dominasi pembangunan perumahan dari segi fisik, serta penilaian terhadap performa perusahaan PT. Aneka Tambang dalam melaksanakan program CSR di bidang perumahan (housing).

\section{a. Peran Negara dan Swasta dalam Pemenuhan Kebutuhan Perumahan}

Program CSR bidang perumahan PT. Aneka Tambang bergerak mengingat lemahnya peran negara dalam menjamin ketersediaan perumahan layak bagi masyarakat yang berada di sekitar kecamatan Nanggung kabupaten Bogor. Perumahan yang menjadi kebutuhan pokok masyarakat dalam menjalani kehidupan merupakan suatu hal yang sulit untuk dipenuhi dengan alasan keterbatasan ekonomi yang menjadikan masyarakat tidak mampu mengakses rumah sesuai dengan standar kesehatan maupun standar keamanan. Kehadiran PT. Aneka Tambang dalam melaksanakan program CSR bidang perumahan mengingat tanggungjawab sosial perusahaan melakukan aktivitas dan berkaitan dengan kehidupan masyarakat yang menjadi tanggungjawab perusahaan atas kesejahteraannya.

Jaminan masyarakat untuk mengakses perumahan sesuai standar kesehatan dan keamanan semestinya merupakan tanggungjawab negara 
sebagai bentuk perlindungan warga negara terhadap kesejahteraan. Negara memiliki kebijakan yang mengatur tata kelola perumahan serta standar minimum untuk rumah sebagai tempat tinggal sehat dan aman serta menjamin keberlangsungan kehidupan yang terdapat di dalamnya ${ }^{15}$. Masih banyak warga masyarakat yang belum memiliki akses untuk mendapatkan tempat tinggal dengan standar kesehatan dan keamanan yang layak dapat dikatakan sebagai salah satu program pemerintah yang kurang berfokus pada kesejahteraan sosial masyarakat. Negara masih didominasi oleh kegiatan perekonomian untuk mengejar ketertinggalan serta stabilitas dalam ranah internasional.

Murie $^{16}$ mengatakan bahwa negara bertindak sebagai kontrol terhadap kelangsungan kehidupan warga masyarakat serta sebagai instrumen dalam penyelesaian persoalan yang dihadapi pada kehidupan masyarakat. Permasalahan keterbatasan akses perumahan sesuai dengan standar kesehatan dan keamanan menjadi jaminan negara dalam menjaga kelangsungan hidup warga negara sehingga menciptakan kesejahteraan dalam jangka panjang. Berbeda halnya yang terjadi di daerah sekitar pertambangan PT. Aneka Tambang. Sebagian besar masyarakat hidup dengan kondisi rumah yang dapat dikatakan tidak layak huni, sehingga mengharuskan program CSR dilaksanakan di bidang perumahan.

Pelaksanaan program CSR perusahaan yang yang dominan pada suatu tatanan masyarakat tertentu dalam jangka panjang dapat menjadikan suatu ketimpangan pandangan terhadap keberadaan negara sebagai penjamin kesejahteraan kehidupan warga negara ${ }^{17}$. Tarik menarik program perbaikan rumah yang banyak dilakukan swasta (perusahaan) menjadikan komunikasi antara masyarakat dan perusahaan menjadi intens sehingga tidak jarang

${ }^{15}$ H. Hikmah \& L. Dharmawan, "Peran Corporate Secretary Dalam Rangkaian Event Hut Ke-22 PT. Pertamina Patraniaga", Jurnal Resolusi Konflik, CSR dan Pemberdayaan (Care), 4(1), 2019, Hal. 58.

${ }^{16}$ Alan Murie \& Peter Malpass, Housing Policy and Practice. (London: MacMillan Education Ltd. 1987), Hal. 47

17 M. A. Abdullah \& A. Firmansyah, "Manajemen Kesehatan Ternak Sapi Potong di Desa Sugihwaras, Kecamatan Sukakarya, Kabupaten Musirawas, Sumatera Selatan", Jurnal Resolusi Konflik, CSR Dan Pemberdayaan (CARE), 2(2), 2019, Hal. 15 
terjadi pergolakan politik oleh sebagian elite tertentu yang tidak berpihak untuk kehidupan masyarakat yang lebih baik.

Kehadiran perusahaan sebagai penjamin ketersediaan akses perumahan yang layak dan sesuai standar kesehatan dapat dijadikan alat untuk pemenuhan kebutuhan perumahan masyarakat sebagai bentuk upaya pengurangan program yang dilakukan oleh pemerintah. Kemungkinan beberapa oknum dan aparat negara dalam hal ini adalah pemerintah maupun perangkat desa menjadikan perusahaan sebagai ladang untuk mengambil keuntungan, baik secara langsung maupun secara tidak langsung. Pelaksanaan program CSR bidang perumahan sebaiknya menjadikan perusahaan sebagai penunjang jaminan sosial untuk akses perumahan bagi masyarakat yang terkena dampak aktivitas sekitar pertambangan. Harapan dari program CSR tidak menjadikan negara lepas tangan dalam menjamin kesejahteraan masyarakat, namun yang diharapkan dari kegiatan program tersebut adalah terciptanya komunikasi yang baik antara pihak pemerintah dan swasta dalam menjamin kesejahteraan masyarakat, terutama mengenai akses perumahan layak.

\section{b. Program Housing dengan Pendekatan Komunitas}

Program CSR PT. Aneka Tambang di bidang perumahan yang dilaksanakan di kacamatan Nanggung kabupaten Bogor menggunakan pendekatan komunitas dalam menjalani program-program yang diturunkan oleh perusahaan. Pelaksanaan program melalui pendekatan komunitas terlihat dari model pelaksanaan lomba perbaikan rumah dan perbaikan rumah sehat mengedepankan asas musyawarah. Penentuan penerima bantuan perbaikan rumah ditentukan oleh Kepala Desa dengan persetujuan masyarakat yang terdapat di desa tersebut.

Pelaksanaan perbaikan rumah dilaksanakan dengan bergotong-royong antar sesama warga mengingat biaya yang diturukan tidak memadai jika seluruh perbaikan dilakukan oleh tukang, apalagi dengan model tender proyek. Kegiatan bersama yang dilaksanakan masyarakat mencerminkan 
suatu bentuk kehadiran masyarakat atau society dalam pelaksanaan program CSR, sehingga diharapakan kesadaran masyarakat tentang community development akan terus berlanjut meskipun perusahaan sudah tidak melaksanakan aktivitas pertambangan.

Kegiatan community development yang dilaksanakan masyarakat dalam program lanjutan CSR dapat menghadirkan sikap dan etos kerja yang sesuai dengan tatanan nilai yang telah dianut oleh masyarakat setempat. Pelaksanaan kegiatan bersama akan menjadi suatu jalan dalam mengatasi persoalan kemiskinan, kejahatan dan meningkatkan kerjasama serta jalinan komunikasi yang terdapat dalam hubungan masyarakat. ${ }^{18}$ Hubungan baik yang terjalin pada masyarakat menjadi modal dalam pembangunan berkelanjutan termasuk sebagai salah satu jaminan atas warga masyarakat dalam memperoleh akses rumah sesuai standar kesehatan dan keamanan, baik dari negara maupun dari pihak swasta sebagai bentuk kegiatan CSR perusahaan.

\section{c. Implementasi Program dan Kecenderungan Performa}

Implementasi program CSR sebagai tanggungjawab perusahaan memiliki tujuan sebagai jaminan atas kesejahteraan masyarakat yang bertempat tinggal serta memiliki aktivitas yang bersinggungan dengan aktivitas pertambangan. Mainstreaming CSR menjadi suatu landasan bagi pelaksanaan dan perencanaan program yang akan dilakukan. Mainstreaming CSR mengharapkan suatu program CSR berasal aspirasi dari masyarakat sebagai penerima bantuan dan perusahaan sebagai pemberi bantuan, serta pelaksanaan kegiatan sebagai bentuk tantangan yang diberikan kepada pelaksana maupun pada penerima bantuan. ${ }^{19}$

Program CSR bidang perumahan PT. Aneka Tambang dalam pelaksanaan lomba dan perbaikan rumah sehat menjadi suatu acuan bahwa

\footnotetext{
18 John J. Egan dkk., Housing and Public Policy: A Role for Mediating Sructures. (Cambridge: Ballinger Publishing Company. 1981), Hal. 16

${ }^{19}$ F. Maon dkk., "Mainstreaming Corporate Social Responsibility: A Triadic Challenge from A General Management Perspective", dalam Professionals perspectives of Corporate Social Responsibility, (New York: Springer, 2009), Hal. 76
} 
program yang dilaksanakan merupakan tindakan atas aspirasi yang berasal dari masyarakat. Pada program perumahan di sekitar perusahaan PT. Aneka Tambang lebih banyak berasal dari mainstreaming perusahaan sebagai bentuk tanggungjawab sosial dalam bentuk jaminan atas akses rumah sehat bagi warga yang terkena aktivitas pertambangan. Mainstreaming CSR dalam menerima asprasi masyarakat tidak terlihat dalam pelaksanaan program perumahan dan perbaikan perumahan yang dilakukan oleh PT. Aneka Tambang, karena program yang dilaksanakan merupakan bentuk mandating bagi perusahaan yang berkaitan dengan aktivitas pertambangan dan dituntut melaksanakan program CSR sebagai bentuk tanggungjawab sosial perusahaan.

Program CSR sebagai mandating sesuai dengan regulasi yang diturunkan kepada perusahaan yang memilki aktivitas di bidang pertambangan merupakan suatu bentuk performa PT. Aneka Tambang dalam menjalankan program CSR. Mandating yang dimaksud adalah keharusan atau suatu tanggungjawab bagi perusahaan untuk menjamin keberlangsungan kehidupan masyarakat serta mendukung peningkatan kesejahteraan sosial bagi warga masyarakat setempat. Performa CSR PT. Aneka Tambang secara mandating dapat juga dikatakan sebagai kesepakatan atas aturan yang diturunkan negara dalam hal ini merupakan kesepakatan yang harus dipenuhi untuk keberlangsungan aktivitas perusahaan.

Berbeda halnya, jika PT. Aneka Tambang melakukan pelaksanaan program CSR bidang perumahan atas dasar bentuk hubungan baik antara perusahaan dan masyarakat sekitar. Kegiatan CSR yang didasari dengan hubungan baik sebagai jaminan atas keberlangsungan kegiatan dan aktivitas pertambangan merupakan bentuk performa perusahaan dalam meraup keuntungan yang bersifat ekonomis. Program CSR dilaksanakan dengan harapan terbukanya jalan yang lebih baik untuk aktivitas perusahaan sehingga program pemberdayaan masyarakat menjadi suatu bentuk hubungan bisnis yang tentunya akan menguntungkan pihak perusahaan. 


\section{d. Dominasi Pembangunan Fisik atas Program Housing}

Persepsi dalam pembangunan dan pelaksanaan program CSR bidang perumahan sering didominasi oleh pembangunan fisik rumah. Pelaksanaan program perumahan diukur dengan konstruksi pembangunan perumahan, kombinasi material dan jenis pembangunan yang dilakukan, serta level kesulitan pembangunan rumah hingga menuju penyelesaian suatu bentuk rumah yang siap untuk digunakan. ${ }^{20}$ Pembangunan perumahan (bousing) identik dengan pembangunan fisik sebagai pelaksanaan program menjadi bentuk nyata yang memudahkan dalam pelaporan serta pertanggungjawaban program yang diturunkan, baik oleh perusahaan maupun pihak pemerintah.

Pembangunan perumahan dengan dominasi pembangunan fisik menjadikan program pemberdayaan masyarakat terkesan sebatas proyek yang harus segera ditunaikan sebagai tanggungjawab, dan sangat jarang untuk menjadikan suatu pemberdayaan sebagai pembangunan berkelanjutan. Sustainable development sangat dibutuhkan sebagai bentuk pemberdayaan masyarakat sehingga diharapkan masyarakat mampu menciptakan suasana lingkungan rumah sebagai tempat ideal untuk beraktivitas dalam kehidupan sehari-hari. Rumah diartikan sebagai tempat tinggal dan tempat menjalani aktivitas masyarakat, sehingga pembinaan serta jaminan keamanan menjadi suatu hal yang dibutuhkan oleh masyarakat untuk meningkatkan taraf hidup sehingga menjadikan kenyamanan atas kehidupan masyarakat.

Program CSR bidang perumahan oleh PT. Aneka Tambang sekilas masih terlihat sebagai program pembangunan dan perbaikan rumah dalam bentuk fisik. Data-data perbaikan perumahan yang didapatkan berupa perubahan material dan bentuk susunan rumah serta pemenuhan kebutuhan dan prasarana penunjang rumah memperlihatkan program CSR

${ }^{20}$ Orville F. Grimes, Housing for Low-Income Urban Families, (New York: The World Bank, 2001), Hal. 3 
bidang perumahan PT. Aneka Tambang masih belum sampai pada taraf pembangunan perumahan model pendekatan pemberdayaan masyarakat dengan basis suntainable development. Program CSR bidang perumahan semestinya juga didominasi oleh pelaksanaan pemberdayaan masyarakat, peningkatan mutu, dan jaminan keamanan dalam manjalani kehidupan di keluarga serta jaminan sosial dalam regulasi perumahan sebagai tempat berlangsungnya aktivitas masyarakat. ${ }^{21}$

Pelaksanaan program CSR di bidang perumahan tanpa dominasi pembangunan fisik rumah, namun juga pembangunan berkelanjutan atas kehidupan dan peningkatan kesejahteraan keluarga diharapkan memunculkan suatu langkah pembangunan masyarakat secara berkelanjutan. Pembangunan perumahan menjadi tolak ukur keberhasilan program CSR bidang perumahan, sehingga diharapkan akan tercipta masyarakat yang mandiri dan memiliki akses dalam meningkatkan kesejahteraan keluarga pasca dilaksanakan kegiatan CSR oleh perusahaan. Pembangunan yang berkelanjutan di bidang perumahan merupakan bentuk jaminan atas kesejahteraan warga masyarakat dalam menjalani kehidupan untuk jangka panjang.

\section{Kesimpulan dan Rekomendasi}

Perusahaan dalam program CSR bidang perumahan hadir sebagai upaya mengisi kekosongan yang tidak dapat dipenuhi oleh negara dalam menjamin akses perumahan bagi masyarakat. Perusahaan memiliki tanggungjawab sosial untuk meningkatkan taraf hidup dan kesejahteraan masyarakat, terutama bagi yang terkena dampak aktivitas perusahaan. PT. Aneka Tambang dalam hal ini menjadi suatu perusahaan yang melaksanakan program CSR di bidang perumahan. Program CSR bidang perumahan PT. Ankea Tambang dilaksanakan di kecamatan Nanggung kabupaten Bogor dengan melaksanakan beberapa kegiatan program pembangunan perumahan. Program yang dilakukan oleh PT. Aneka Tambang adalah lomba perbaikan rumah dan pelaksanaan perbaikan rumah sehat yang

\footnotetext{
${ }^{21}$ Orville F. Grimes, Housing for... hal. 5.
} 
menjadi tolak ukur atas jaminan akses perumahan bagi masyarakat sebagai bentuk tanggungjawab sosial perusahaan.

Rekomendasi yang dapat diberikan untuk perbaikan program CSR bidang perumahan PT. Aneka Tambang adalah dengan memperhatikan persoalanpersoalan yang dihadapi oleh PT. Aneka Tambang dalam melaksanakan program pembangunan perumahan. (1) Program CSR yang dilakukan perusahaan baik di bidang perumahan maupun yang lain dalam rangka menunjang kesejahteraan hidup masyarakat tidak menjadikan perusahaan sebagai pengganti peran negara dalam penjamin kesejahteraan masyarakat, karena jaminan kesejahteraan merupakan tanggungjawab negara, sementara perusahaan menjadi pendukung atas programprogram yang dilaksanakan. (2) Peningkatan pelibatan komunitas dalam pelaksanaan program pemberdayaan masyarakat merupakan bentuk jaminan sosial jangka panjang. (3) Peningkatan performa perusahaan dalam menjalankan program CSR menjadi bagian yang akan menunjukan keterlibatan perusahaan terhadap peningkatan kesejahteraan masyarakat di sekitar aktivitas perusahaan. (4) Selain melaksanakan pembangunan fisik, dominasi pembangunan sosial juga menjadi tujuan program CSR bidang perumahan dalam rangka peningkatan kesejahteraan masyarakat secara berkelanjutan.

Program-program yang direkomendasikan sebagai kegiatan berkelanjutan dapat didesain dengan penggalian lebih dalam terhadap persoalan masyarakat secara mendasar. Banyak program yang dilakukan beberapa instansi yang memiliki fokus dalam peningkatan kesejahteraan tidak bertahan lama karena terkendala dengan program yang hanya sebatas charity. Seperti kegiatan perbaikan rumah dapat digolongkan ke dalam program fisik yang tentunya akan sulit untuk dilaksanakan dalam jangka panjang. Rekomendasi yang dapat diadopsi atas penyempurnaan program ini seperti: (1) Program desa mari (maju dan mandiri), kegiatan ini bertujuan untuk bagaimana menumbuhkan keinginan masyarakat tetap menjaga dan meningkatkan kualitas perumahan. (2) Program lomba rumah bersih, kegiatan ini bertujuan untuk monitoring terhadap perbaikan rumah yang sudah diberikan program perbaikan, dengan harapan masyarakat memiliki kesadaran sendiri untuk 
melanjutkan program, dan (3) Program rumah goro (gotong royong), kegiatan ini memiliki tujuan untuk meningkatkan perbaikan rumah dilakukan dengan kekuatan kebersamaan meskipun tetap disokong oleh perusahaan dari segi pendanaan, sehingga masyarakat memiliki komitmen bersama untuk mewujudkan perumahan atau housing yang berimbang.

\section{Daftar Pustaka}

Abdullah, M. A., \& Firmansyah, A. Manajemen Kesehatan Ternak Sapi Potong di Desa Sugihwaras, Kecamatan Sukakarya, Kabupaten Musirawas, Sumatera Selatan. Jurnal Resolusi Konflik, CSR Dan Pemberdayaan (CARE), 2(2). 2019. https://journal.ipb.ac.id/index.php/jurnalcare/article/view/26292

Beauchamp, Tom L., Cause Studies in Business, Society, and Ethics. New Jersey: Englewood Cliffs. 1989.

Egan, John J., dkk. Housing and Public Policy: A Role for Mediating Sructures. Cambridge: Ballinger Publishing Company. 1981.

Fadri, Zainal. Upaya Penanggulangan Gelandangan Dan Pengemis (Gepeng) Sebagai Penyandang Masalah Kesejahteraan Sosial (PMKS) Di Yogyakarta. Komunitas, 10(1), 1-19. 2019.

Fadri, Zainal. Tabuik: Local Wisdom as an Alternative for Suppressing the Impact of Structural Change in Pariaman. Alfuad: Jurnal Sosial Keagamaan, 3(1). 97109. 2019

Grimes, Orville F. Housing for Low-Income Urban Families. New York: The World Bank. 2001.

Handayani, Yohana Lilis., Sujaymoko, Bambang \& Sutikno, Sigit. Implementation of Rapid Sand Filter for Groundwater Treatment in Kulim Tenaya Raya Pekanbaru. Jurnal Sinergitas PKM \& CSR, 1(2). 2017.

Hikmah, H., \& Dharmawan, L. Peran Corporate Secretary Dalam Rangkaian Event Hut Ke-22 Pt Pertamina Patraniaga. Jurnal Resolusi Konflik, Csr Dan Pemberdayaan (Care), 4(1), 56-60. 2019.

Kho, Katherine., Aslanzadeh, Soimaz., Muslimatun, Siti \& Devanthi, Putu Virgina Partha. Latihan Manajemen Pengolahan Sampah bagi Maysarakat Kelurahan Cempaka Putih, Jakarta. Jurnal Sinergitas PKM dan CSR, 4(1). 2019.

Laquian, Aprodicio A. Basic Housing: Policies for Urban Sites, Services, and Shelter in Developing Countries. Ottawa: International Development Research Center. 1983. 
Malpass, Peter. Housing Policy and the Housing System. dalam Implementing Housing Policy. Buckingham: Open University Press. 1993.

Maon, F., dkk., Mainstreaming Corporate Social Responsibility: A Triadic Challenge from A General Management Perspective. dalam Professionals perspectives of Corporate Social Responsibility. New York: Springer. 2009.

Murie, Alan dan Malpass, Peter. Housing Policy and Practice. London: MacMillan Education Ltd. 1987.

Musrifah. Penerapan Corporate Social Responsibility (CSR) bidang Perumahan pada Wilayah Binaan PT. Aneka Tambang Tbk. di Kecamatan Nanggung Kabupaten Bogor. Semarang: Universitas Diponegoro. 2010.

Putri, M., \& Maknun, I. Pemberdayaan Masyarakat Melalui Pendidikan Lingkungan di PAUD Alam Al Firdaus, Desa Muktijaya, Kecamatan Cilamaya Kulon, Karawang. Jurnal Resolusi Konflik, CSR Dan Pemberdayaan (CARE), 3(1). 2019.

Sen, Amartya. Economics, Business Princples, and Moral Sentiments. dalam Business Ethics: Vol I, Ethical Theory, Distibutive Justice, and Social Responsibility. London: SAGE Publication Inc. 2006.

Sudarwati, Nanik. Kebijakan Pengentasan Kemiskinan. Malang: Intimedia. 2009.

Syarifah, N. L. Program Pengembangan Pertanian Terpadu untuk Meningkatkan Pendapatan dan Kesejahteraan Masyarakat di Wilayah Operasi PT Pertamina EP Asset 2 Field Adera. Jurnal Resolusi Konflik, CSR Dan Pemberdayaan (CARE), 2(2). 2019.

Zaenurrossyid, A. \& Nuruddin, Ahmad. Modal Sosial Pesantren Jawa Pesisiran Utara dalam Pemberdayaan Masyarakat. Islamic Review: Jurnal Riset dan Kajian Keislaman, 8(1). 2019.

Zaenurrossyid, A. \& Sulikhah, Siti. Paradigma Fiqh Sosial Atas Kemiskinan dalam Gerakan Empowering Menuju Kemakmuran Umat. Islamic Review: Jurnal Riset dan Kajian Keislaman, 6(1). 2017. 
Studi Terhadap Program Housing... 